\title{
Histological Alterations in Organs of African Giant Catfish (Heterobranchus bidorsalis) Fingerlings Exposed to Copper Sulphate
}

\author{
Temitope JEGEDE ${ }^{1}$ \\ ${ }^{1}$ Department of Forestry, Wildlife and Fisheries Management, Ekiti State University, Ado Ekiti, Nigeria \\ Correspondence: Temitope JEGEDE, Department of Forestry, Wildlife and Fisheries Management, Ekiti State \\ University, Ado Ekiti, Nigeria. E-mail: temitopejegede@yahoo.com
}

\author{
Received: November 30, 2012 Accepted: December 20, 2012 Online Published: February 17, 2013 \\ doi:10.5539/jas.v5n3p254 URL: http://dx.doi.org/10.5539/jas.v5n3p254
}

\begin{abstract}
Static bioassay was conducted to determine the $96 \mathrm{~h}$ median lethal level $\left(\mathrm{LC}_{50}\right)$ of copper sulphate on Heterobranchus biborsalis fingerlings ( $5.84 \pm 0.5 \mathrm{~g}$ and length of $6.00 \pm 1.0 \mathrm{~cm}$ respectively) and to describe the histological changes in the gill, liver, kidney, intestine and heart. $\mathrm{LC}_{50}$ of $\mathrm{H}$. bidorsalis fingerlings was determined graphically as $0.39 \mathrm{ppt}$. Fish displayed the following behaviors jumping out of the tank (at higher concentration), erratic swimming, discoloration, hyperventilation, irregular operculum and tail beat frequencies and loss reflex during $96 \mathrm{~h}$ exposure. Histological examination revealed that gill architecture was destroyed and erosion of gill lamellae, raker and edema. The liver showed distorted liver cells, severe vacuolation of the hepatocytes, fibrosis, coagulative necrosis in the liver parenchyma and round cell infiltration, in the hepatic parenchyma. The kidney showed enlarged globular lumen and damage of proximal tubules, vacuolization and lesions at the highest concentration of copper sulphate. Also the intestine revealed severe degeneration and necrotic changes in the intestinal mucosa cells and submucosa. Lastly the heart showed degeneration of cardiac muscle fiber, atrophy of the cardiac muscle fiber and edema of the atro-ventricular funnel near the entrance of the ventricle on exposure to high concentrations of copper sulphate.
\end{abstract}

Keywords: histological alterations, copper sulphate, Heterobranchus bidorsalis

\section{Introduction}

In aquaculture, copper sulphate is used to treat virtually all diseases (Wani et al., 2011; Moore et al., 1984). It is an algaecide (Watson \& Yanong, 2006), it is anti-bacterial, anti-fungal, works against external protozoa such as Ich, and also works against Oodinium, Sliminess of the skin and kills certain parasites such as Cryptocaryon irritans (Salt water Ich) and Crustacea (Argulus) (Watson \& Yanong, 2006). It is also used in killing snails and slugs in irrigation as well as municipal water treatment systems (Moore et al., 1984). It also works as a great preventative treatment for most fish, both freshwater and saltwater fish. Copper forms an essential part of variety of enzymes (free radical defense) and liver proteins homocuprien and heptacuprien (Seymore, 1994). Despite the essential role of copper in a number of vital biochemical processes, the metal is known to induce several histopathological changes in fish organs, when present in higher concentration in water (Vutukuru et al., 1993). Copper accumulation in organs of animals of polluted water bodies (Al-Kahtani, 2009) leads to generation of free radicals which causes the biochemical and morphological alterations in them (Monteiro et al., 2005; Varanka et al., 2001). It is non biodegradable but easily assimilated and bio-accumulated (Okoye et al., 1991).

Though several research works had been conducted on the effect of copper sulphate on fish, but its toxicity varies with the species of fish and the physical and chemical characteristics of water (New York State Department of Health, 1984) and this has necessitated this present study.

The genus Heterobranchus is endemic to Africa (Teugel, 1982). Heterobranchus bidorsalis is the second most important Clariid catfish used in aquaculture in Nigeria (Adewumi, 2005; Vanden Bossche \& Bernacsek, 1990; Fagbenro et al., 1993).

This study is therefore aimed to determining the lethal concentration $\left(\mathrm{LC}_{50}\right)$ value of Heterobranchus bidorsalis fingerlings exposed to varying concentrations of copper sulphate and to determine the effects of copper sulphate on the histology of gills, liver, kidney, intestine and heart tissues of Heterobranchus bidorsalis fingerlings. 


\section{Materials and Methods}

Two hundred apparently healthy fingerlings of Heterobranchus bidorsalis from mixed sex and the same brood stock, mean weight and length of $(5.84 \pm 0.5 \mathrm{~g})$ and $(6.00 \pm 1.0 \mathrm{~cm})$ respectively were procured from Adebayo fish farm Ado Ekiti, Ekiti State, Nigeria. They were transported alive to Fisheries Management laboratory of Ekiti State University, Ado Ekiti, Ekiti State in 50 liter capacity plastic containers, half filled with pond water between $1700-1730 \mathrm{~h}$. They were later stocked in rectangular plastic tank $(75 \mathrm{~cm} \mathrm{x} 40 \mathrm{~cm}$ x $40 \mathrm{~cm})$ of 45 -liter capacity where they are allowed to acclimatize for 7 days. Ten H. bidorsalis fingerlings $(5.84 \pm 0.5 \mathrm{~g})$ were stocked into each rectangular plastic tank $(75 \mathrm{~cm} \times 40 \mathrm{~cm} \times 40 \mathrm{~cm})$, with three replicates per treatment. Copper sulphate pentahydrate $\left(\mathrm{CuSO}_{4} \cdot 5 \mathrm{H}_{2} \mathrm{O}\right)$ were obtained from an Agro- allied shop in Ado Ekiti, Ekiti State, Nigeria and kept in a dry, clean, air-tight well labelled transparent plastic container. Copper sulphate pentahydrate $\left(\mathrm{CuSO}_{4} \cdot 5 \mathrm{H}_{2} \mathrm{O}\right)$ were measured and weighed by using a Metler top-loading balance (Model P13 8001).

Dilution technique was used in dissolving copper sulphate pentahydrate $\left(\mathrm{CuSO}_{4} \cdot 5 \mathrm{H}_{2} \mathrm{O}\right)$ in water prior toxicity test and citric acid was added to enhance dissolution. The treatments were: Treatment $1,0.10 \mathrm{mg} \mathrm{CuSO} / / \mathrm{L}^{-1}$ of water; Treatment 2, $0.20 \mathrm{mg} \mathrm{CuSO}_{4} / \mathrm{L}^{-1}$ of water; Treatment $3,0.30 \mathrm{mg} \mathrm{CuSO}_{4} / \mathrm{L}^{-1}$ of water; Treatment $4,0.40 \mathrm{mg}$ $\mathrm{CuSO}_{4} / \mathrm{L}^{-1}$ of water, Treatment 5, $0.50 \mathrm{mg} \mathrm{CuSO}_{4} / \mathrm{L}^{-1}$ of water and Control, $0 \mathrm{~g} \mathrm{CuSO}_{4} / \mathrm{L}^{-1}$ of water. Standard methods (APHA, 1998) were employed in carrying out the experiment.

Prior to the commencement of the experiment, the fish were starved for 2 days to minimize the amount of waste in the test media and to prevent organic decomposition and oxygen depletion. The experiment was conducted under standard static bioassay conditions. Temperature, $\mathrm{pH}$, dissolved oxygen, and conductivity level were determined using standard methods and readings were taken at $24 \mathrm{~h}$ interval for $96 \mathrm{~h}$. At the end of the treatment period, two fish from each treatment tank were removed, weighed, killed by decapitation and vital organs such as the gill, liver and kidney were removed, fixed for $24 \mathrm{~h}$ in formalin-saline solution made of equal volumes of $10 \%$ formalin and $0.9 \% \mathrm{NaCl}$ solution. Histological sections of $8 \mu$ thickness were prepared following standard procedures (Chieli et al., 1995) photomicrographs were taken with Leitz (Ortholux) microscope and camera.

\section{Results}

The following behaviors were exhibited during the definitive test; jumping out of the tank (at higher concentration), erratic swimming, discolouration, hyperventilation, irregular operculum and tail beat frequencies and loss reflex. Fish mortality at varying concentrations increased with increasing concentration of copper sulphate. All fish in the control treatment survived throughout the 96 hours duration of the experiment. The cumulative mortalities and acute $96 \mathrm{~h} \mathrm{LC}_{50}$ of copper sulphate on fingerlings of Heterobranchus bidorsalis was determined according to Behrens-Karber's method (Klassen, 1991).

There were significant losses of fish with increase in copper sulphate concentration $(\mathrm{P}<0.05)$. The $\mathrm{LC}_{50}$ as recorded graphically at $0.39 \mathrm{mg}$ CUSO $4 / \mathrm{L}^{-1}$ of water (Figure 1).

Histological changes in organs (gill, liver, kidney, intestine and heart) of $H$. bidorsalis fingerlings were represented in Tables 1, 2, 3, 4, and 5 .

Table 1. Histological changes in gills of H. bidorsalis fingerlings exposed to copper sulphate toxicity

\begin{tabular}{ll}
\hline $\begin{array}{l}\text { Concentration } \\
(\mathrm{mg} / \mathrm{L})\end{array}$ & Histological observation \\
\hline 0 & $\begin{array}{l}\text { Normal gill architecture (Mucoid epithelium, gill filament and secondary lamella } \\
\text { distinctively separated). }\end{array}$ \\
0.10 & $\begin{array}{l}\text { No visible alteration was noticed. } \\
\text { Slight vacuolation was observed. } \\
0.20\end{array}$ \\
0.30 & $\begin{array}{l}\text { Epithelium proliferation of mucous cells and hyperplasia. Fusion of secondary lamella and } \\
\text { gill filaments } \\
\text { Lifting of lamellar epithelium and edema. } \\
0.40\end{array}$ \\
0.50 & $\begin{array}{l}\text { Degeneration of the gill architecture (erosion of the gill filament and gill rakers) and severe } \\
\text { edema. }\end{array}$ \\
\hline
\end{tabular}


Table 2. Histological changes in liver of H. bidorsalis fingerlings exposed to copper sulphate toxicity

\begin{tabular}{ll}
\hline $\begin{array}{l}\text { Concentration } \\
(\mathrm{mg} / \mathrm{L})\end{array}$ & Histological observation \\
\hline 0 & Normal hepatocellular architecture. \\
0.10 & Normal liver architecture. \\
0.20 & $\begin{array}{l}\text { No lesion/ no noticeable alteration in the hepatocyte. } \\
\text { Vacuolation of the hepatocytes, and congestion in blood sinusoids. } \\
0.30\end{array}$ \\
0.40 & $\begin{array}{l}\text { Distorted liver cells, severe vacuolation of the hepatocytes and fibrosis in the hepatic } \\
\text { parenchyma. }\end{array}$ \\
0.50 & Coagulative necrosis in the liver parenchyma and round cell infiltration. \\
\hline
\end{tabular}

Table 3. Histological changes in kidney of H. bidorsalis fingerlings exposed to copper sulphate toxicity

\begin{tabular}{ll}
\hline $\begin{array}{l}\text { Concentration } \\
(\mathrm{mg} / \mathrm{L})\end{array}$ & Histological observation \\
\hline 0 & Normal kidney cell and no visible lesion \\
0.1 & No visible alteration in the kidney cell. \\
0.2 & No visible lesion in the kidney cell. \\
0.3 & Necrosis of proximal tubule and glomerular shrinkage. \\
0.4 & $\begin{array}{l}\text { Degeneration of interstitial tissue and renal tubules. } \\
\text { Enlargement of globular lumen and damage of proximal tubules, vacuolization and } \\
0.5\end{array}$ \\
\hline
\end{tabular}

Table 4. Histological changes in intestine of $H$. bidorsalis fingerlings exposed to copper sulphate toxicity

\begin{tabular}{ll}
\hline $\begin{array}{l}\text { Concentration } \\
(\mathrm{mg} / \mathrm{L})\end{array}$ & Histological observation \\
\hline 0 & $\begin{array}{l}\text { Normal intestine structure i.e. mucoid epithelial cells are very visible, normal intestinal folds } \\
\text { and no visible lesions on all the tissues. }\end{array}$ \\
0.10 & No alteration was noticed. \\
0.20 & No lesion was noticed. \\
0.30 & Lesions on the submucosa and mucosa cells \\
0.40 & Edema between the interstitial submucosa and mucosa \\
0.50 & Severe degeneration and necrotic changes in the intestinal mucosa cells and submucosa. \\
\hline
\end{tabular}

Table 5. Histological changes in hearth of $H$. bidorsalis fingerlings exposed to copper sulphate toxicity

\begin{tabular}{ll}
\hline $\begin{array}{l}\text { Concentration } \\
(\mathrm{mg} / \mathrm{L})\end{array}$ & Histological observation \\
\hline 0 & Normal heart architecture. \\
0.10 & No alteration in the heart cell arrangement. \\
0.20 & Slight alteration in the heart cell arrangement \\
0.30 & Degeneration of the cardiac muscle fiber. \\
0.40 & Focal necrosis and vacuolar degeneration of cardiac muscle fiber. \\
0.50 & Atrophy of the cardiac muscle fiber and edema of the atro-ventricular funnel near the \\
& entrance of the ventricle. \\
\hline
\end{tabular}




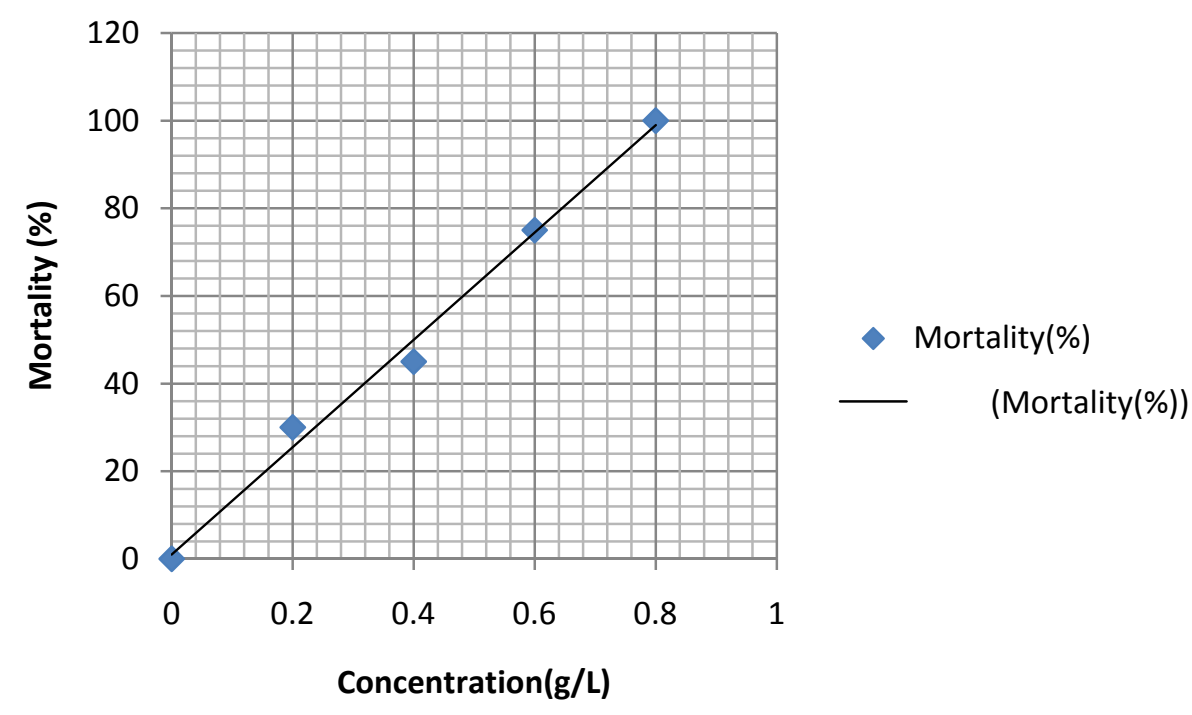

Figure 1. Effect of copper sulphate on mortality of fingerlings of Heterobranchus bidorsalis

\subsection{Water Quality Measurements}

Water samples were collected weekly at a depth from each plastic tank. Dissolve oxygen (DO) and temperature were measured using oxygen meter (YSI model 58, Yellow Spring Instrument Co., Yellow Spring, OH, USA) and mercury in glass thermometer, respectively. $\mathrm{pH}$ was measured with $\mathrm{pH}$ meter (Digital Mini-pH Meter, model 55, Fisher Scientific, Denver, CO, USA). In all treatments, DO concentrations were decreased with the increase in the concentration of copper sulphate from $6.8-4.2 \mathrm{mg} / \mathrm{L}$, water temperature average was $26.4{ }^{\circ} \mathrm{C}$, pH value ranged from 7.4 - 8.0. All the water quality parameters were within the acceptable ranges for fish growth (Environment Protection Authority, EPA (2003).

\section{Discussion}

This study revealed that Heterobranchus bidorsalis fingerlings exposed to various concentration of copper sulphate demonstrated some marked behavioral changes such as jumping out of the tank (at higher concentration), erratic swimming, discoloration, hyperventilation, irregular operculum beat frequencies, irregular tail beat frequencies, loss of reflex and loss of balance, which are sensitive indicators of physiological stress in the fish. In a similar study by Ayotunde and Ofem (2008), increased opercular movement suggests decreased efficiency in oxygen uptake or transport. Also in a similar study by Sharaf and Abdel-Tawwab (2011), fish hypoxia and increased respiration of fish were observed within few minutes after the exposure of Oreochromis niloticus to commercial petroleum fuel.

Lloyd (1992) reported that there are many routes of entry of heavy metals e.g. copper into the body of fish, namely oral ingestion, absorption through gills, general body surface and gastrointestinal tract. After absorption the metal makes its way into the target organ, where it produces various types of disturbances. In this present study the target organs are gill, liver, kidney, intestine and heart.

\subsection{Histological Changes Gill}

Regarding gill histology, the control group reveals normal gill architecture i.e. mucoid epithelium, secondary filament and gill lamella were distinctively visible, no lesion was noticed, while other treatment groups shows alteration in the gill architecture namely epithelial lifting, edema in the filament, fusion of lamellae, epithelium proliferation and haemorrhage. The lifting of lamellar epithelium could be a defense mechanism, because separation of epithelium of the lamellae increases the distance across which copper must diffuse to reach the blood stream (Arellano et al., 1999). The lifting of lamellar epithelium may probably be due to severe edema (Pene et al., 2004). Cell proliferation which results in hyperplasia is one of the major histological changes observed in fishes exposed to copper sulphate as reported by several authors (Figueiredo, 2007; Van Heerden et al., 2004), which leads to lamellar fusion observed in the present study. Hyperplasia of gill epithelium also decreased the surface area available for oxygen diffusion (Lappivara, 1995). 


\subsection{Liver}

The liver plays a central role in the metabolism of foreign substances.

With relation to liver histology, the control group revealed normal hepato-cellar architecture, which is similar to the normal liver architecture of tilapia as described by Morrison et al. (2006). While other treatment groups showed alteration in the liver cell arrangement namely; vacuolation and congestion in blood sinusoids, distorted liver cells, severe vacuolation, fibrosis in the hepatic parenchyma and coagulative necrosis in the liver parenchyma and round cell infiltration. In a similar study, the toxicopathic liver disease of netpen reared salmon revealed the following histological changes associated with the disease; necrosis of individual hepatocytes and bile preductule cell proliferation and as netpen liver disease (NLD) progresses, diffused necrosis, vacuolation and megalocytosis of liver parenchyma were observed (Kent, 1990).

\subsection{Kidney}

Concerning histological changes in kidney, the control revealed normal kidney histology (Morrison et al., 2006). No noticeable alteration and lesion, while treatments 1 and $2(0.1 \mathrm{mg} \mathrm{CuSO} / \mathrm{L}$ and $0.2 \mathrm{mg} \mathrm{CuSO} / \mathrm{L}$ respectively) showed no visible lesion and alterations). Other treatment groups, treatments 4 and $5(0.4 \mathrm{mg} \mathrm{CuSO} / \mathrm{L}$ and $0.5 \mathrm{mg}$ $\mathrm{CuSO}_{4} / \mathrm{L}$ respectively) revealed degeneration interstitial tissue and renal tubules, enlargement of globular lumen, damage of proximal tubules, vacuolation and lesion. In a similar study by Jegede (2007) on the toxic effect of sodium chloride on Oreochromis niloticus fingerlings, it was discovered that at high concentrations, the kidney shape/structure had been distorted also thick dark colorations were seen on the tip of the tissue.

\subsection{Intestine}

As regards intestine histology, the control group revealed normal intestine histology with no lesion Morrison et al., (2006) and Ajani and Akpoilih (2010). Also in treatments 1 and 2 (0.1 and $0.2 \mathrm{mg} \mathrm{CuSO}_{4} / \mathrm{L}$ ) respectively, normal histology were still maintained, no lesion was noticed, mucoid epithelial cells were very visible, but in treatments 3,4 and $5\left(0.3,0.4\right.$ and $\left.0.5 \mathrm{mg} \mathrm{CuSO}_{4} / \mathrm{L}\right)$ showed lesion in the submusa and mucosa cells, edema between the intestinal submucosa and mucosa and treatment $5\left(0.05 \mathrm{mg} \mathrm{CuSO}_{4} / \mathrm{L}\right)$ showed severe degeneration and necrotic changes in the intestinal mucosa cells and submucosa respectively.

In an akin study by Ajani and Akpoilih (2010) where the effect of exposure of common carp to dietary copper and its recovery rate were investigated, fish were fed with elevated copper diets $\left(1000 \mathrm{mg} / \mathrm{kg}^{-1}\right.$ and $2000 \mathrm{mg} / \mathrm{kg}^{-1}$ as diet 1 and diet 2 , respectively) for 42 days. It was observed that the intestine tissue showed mucoid epithelial cell and intestinal fold with no visual lesion. However the discrepancy between the results in the present study and later study is that no visual lesion was observed.

\subsection{Heart}

With respect to histological changes in heart, the control group revealed normal heart histology (Morrison et al., 2006). Treatments $1\left(0.1 \mathrm{mg} \mathrm{CuSO}_{4} / \mathrm{L}\right)$ showed no visible lesion and alterations. Treatment $2\left(0.2 \mathrm{mg} \mathrm{CuSO}_{4} / \mathrm{L}\right)$ showed slight alteration in heart cell arrangement. Also other treatment groups, treatments 3,4 and $5(0.3 \mathrm{mg}$ $\mathrm{CuSO}_{4} / \mathrm{L}, 0.4 \mathrm{mg} \mathrm{CuSO}_{4} / \mathrm{L}$ and $0.5 \mathrm{mg} \mathrm{CuSO}_{4} / \mathrm{L}$ respectively) revealed degeneration of the cardiac muscle fiber, focal necrosis and vacuolar degeneration of cardiac muscle fiber and atrophy of the cardiac muscle fiber and edema of the atro-ventricular funnel near the entrance of the ventricle. In a similar study by Jegede (2007) where the toxicity of sodium chloride was investigated on Oreochromis niloticus fingerlings and it was observed that acute toxicity of sodium chloride on Oreochromis niloticus fingerlings resulted in perforation and deformation of the heart tissue.

\section{Conclusion}

This study had shown the median lethal level $\left(\mathrm{LC}_{50}\right)$ of Heterobranchus bidorsalis fingerlings exposed to copper sulphate toxicity to be $0.39 \mathrm{~g} / \mathrm{L}$. It also revealed the various histological alterations in gill, liver, kidney, intestine and heart of $\mathrm{H}$. bidorsalis fingerlings subjected to varying degrees of $\mathrm{CuSO}_{4}$ toxicity, hence the knowledge of this could help in fish and pond management.

\section{Refrences}

Adewumi, A. A. (2005). Catfish culture in Nigeria: progress, Prospects and Problems. Aquaculture Research, 36, 479-585.

Ajani, E. K., \& Akpoilih, B. U. (2010). Effect of chronic dietary copper exposure on haematology and histology of common carp (Cyprinus carpio L.). J. Appl. Sci. Environ. Manage, 14(4), 39-45. 
Al-Kahtani, M. A. (2009). Accumulation of heavy metals in tilapia fish (Oreochromis niloticus) from Al-Khadoud spring, Al-Hassa, SaudiArabia. American J. Applied Sci., 12, 2024-2029. http://dx.doi.org/10.3844/ajassp.2009.2024.2029

APHA. (1998). Standard Methods for the Examination of Water and Waste Water (20 edn) (p. 1976). New York, USA: American Public Health Association.

Arellano, J. M., Storch, V., \& Sarasquete, C. (1999). Histological changes and copper accumulation in liver and gills of the Senegales sole Solea senegalensis Ecotoxicol. Environ. Saf., 44, 62-72. http://dx.doi.org/10.1006/eesa.1999.1801

Atamanalp, M., Angis, S., Oguzha, S., \& Akakal, E. (2008) Alterations in hematological parameters of rainbow trout (Oncorhynchus mykiss) exposed to DDVP. The Israeli Journal of Aquaculture-Bamidgeh, 60(1), 9-12.

Chieli, E., Romiti, N., Cervelli, F., \& Tongiani, R. (1995). Effects of flavonols on P-glycoprotein activity in cultured rat hepatocytes. Life Sci., 57, 1741-1751.

Environment Protection Authority. (2003). Water Quality Policy an over view and a copy of the Water Quality Policy with an accompanying explanatory report. Retrieved from www.epa.sa.gov.au/pub.html

Fagbenro, O. A., Adedire, C. O., Owoseeni, E. A., \& Ayotunde, E. O. (1993). Studies on the biology and aquacultural potential of feral catfish, Heterobranchus bidorsalis (Geoffroy Saint Hilaire 1809) (Clariidae). Tropical Zoology, 6, 67-79. http://dx.doi.org/10.1080/03946975.1993.10539209

Figueiredo, A., Ferreira, J. V., Garcia, S., Monnteiro, S. M., Carrola, J., Matos, P., \& Fontainhas, A. (2007). Histopathological changes in liver and gill epithelium of Nile tilapia, Oreochromis niloticus exposed to waterborne copper Preq Vet. Bras, 27(3), 103-109.

Jegede, T. (2007) Acute-toxicity of sodium chloride $(\mathrm{NaCl})$ on Oreochromis niloticus fingerlings. Journal of Fisheries International, 2(4), 292-294.

Kent, M. C. (1990). Netpen liver diseases (NLD) of Salmonid fishes reared in sea water: Species susceptiblility, recovery, and probable cause. Diseases of Aquatic Organisms, 8, 21- 28. http://dx.doi.org/10.3354/dao008021

Klassen, C. D. (1991). Principles of toxicology. In A. G. Gilman, T. W. Tall, A. S. Nies, \& P. Tailor (Eds.), Pharmacological Basis of Thrapeutics (8th ed.) (pp. 49-61). Berlin: McGraw-Hill.

Lappivaara, J., Nikinmaa, M., \& Tuurala, H. (1995) Arterial oxygen tension and the structure of the secondary lamellae of the gills in rainbow trout (Oncorhynchus mykiss) after acute exposure to zinc and during recovery, Aquatic toxicol, 32, 321-330. http://dx.doi.org/10.1016/0166-445X(94)00097-A

Lloyd, R. (1992) Pollution and freshwater fish. Fishing new books, London: Blackwell scientific Pub Ltd.

Monteiro, S. M., Mancera, J. M., Fontainhas-Fernandes, A., \& Sousa, M. (2005). Copper induced alterations of biochemical parameters in the gill and plasma of Oreochromis niloticus Comp Biochem. Physio., C(141), 375-383.

Moore, B. K, Mitchell, A. J., Griffin, B. R., \& Huffman, G. L. (1984). Parasite and diseases of pond fishes. Third report of the fish farmers: US fish and wildlife services (p. 56). Washington. D.C.

Morrison, C. M., Fitzsimmons, K., \& Wright, Jr. J. R. (2007). Atlas of tilapia histology. World Aquaculture Society, US.

Okoye, B. C. C., Ogunlowo, S. O., \& Nwankwoala, A. U. (1991). Heavy metals in organisms in the Lagos lagoon. Int. J. Environ. Stud., 37, 285-292. http://dx.doi.org/10.1080/00207239108710641

Pane, E. F., Haque, A., \& Wood, C. M. (2004). Mechanistic analysis of acute, nickel induced respiratory toxicity in the rainbow trout (Oncorhynchus mykiss ): an exclusively branchial phenomenon. Aquat. Toxicol., 69, 11-24. http://dx.doi.org/10.1016/j.aquatox.2004.04.009

Seymore, T. (1994). Bioaccumulation of metals in Barbus marequensis from the Olifants River, Kruger National Park and the lethal levelsof manganese to juvenile Oreochromis mossambicus. M.Sc. Thesis, RandAfrikaans University, South Africa.

Sharaf, S. M., \& Abdel-Tawwab, Y. (2011). Eco-physiological impact of commercial petroleum fuels on Nile tilapia, Oreochromis niloticus. In L. P. Liu, \& F. Kelvin (Eds.), Proceedings of $9^{\text {th }}$ International Symposium on Tilapia in Aquaculture (pp. 28-38). 
Teugels, G. G. (1982). Preliminary results of a morphological study of five African species of the subgenus Clarias ( Pisces: Clariidae). Journal of Natural History, 16, 439-464. http://dx.doi.org/10.1080/00222938200770351

Van Heerden, D., Tiedt, L. R., \& Vosloo, A. (2004). Gill damage in Oreochromis mossambicus and Tilapia sparrmanii after short-term copper exposure. Elsevier Int. Cong. Ser., 1275, 195-200.

Vanden Boscche, J. P., \& Bernacsek, G. M. (1990). Source book for the inland fishery resources of Africa: 2. CIFA Technical Paper No. 18.2. FAO, Rome.

Vardhani, V. V., \& Gowri, P. (2002). Antigen induced histopathological changes in liver and kidney of Leabeo rohita. J. Ecotoxicol. Moint, 12(1), 209-213.

Vutukuru, S. S., Suma, C. H., Radha, K., Juveria, S. J., Venkateswara, J., \& Anjaneyula, Y. (2005). Studies on the development of potential biomarker for rapid assessment of copper toxicity to freshwater, fish using Esomus danricus as model. Int. J. Environ. Res. Public Health, 2(2), 253-257.

Wani, A. A., Sikdar-Bar, M., Borana, K., Khan, H. A., Rabi, S. S. M., \& Pervaiz, P. A. (2011). Histopathological Alterations Induced in Gill Epithelium of African Catfish, Clarias gariepinus, Exposed to Copper Sulphate. Asian Journal of Experimental Biological Science, 2(2), 278-282.

Watson, C., \& Yanong, R. P. E. (2006). Use of Copper in Freshwater Aquaculture and Farm Ponds. In Fact Sheet of Food and Agricultural Science FA-13.Department of Fisheries and Aquatic Science. Florida Cooperative Extension Services. University of Florida. Retrieved from www.nationalfishpharm.com 